\title{
各種高級鋳鉄管の疲労強度についで
}

$$
\begin{aligned}
& \text { 小西 一 郎** 薄 田正一林* } \\
& \text { 勝 田 良 雄***島田喜十郎** }
\end{aligned}
$$

\section{On the Fatigue Strength of Various High Grade Cast Iron Pipes}

by

\author{
Ichirō Konishi, Masakazu UsudA, Yoshio Katsuta
}

(Kyoto University) (Hanshin Water Supply Association)

\author{
and Kijürō SHIMADA \\ (Kyoto University)
}

Recently, not a few rupture accidents of distribution pipes of water works have occurred at some cities in our country. The pipes ruptured were of high grade cast iron and had been considered to be safe from rupture, because their construction was not very old as we might expect such accidents.

To clarify the cause of the accidents from the view point of the strength of pipe, some static and fatigue tests were made, to which were put rectangular test pieces taken out from bodies of various pipes, that is, the pieces from ruptured pipes and unused pipes manufactured in different years.

Along with those tests, determination of chemical compositions and comparison of microstructures of cast iron were made.

Some of the test results obtained are as follows:

(1) The microstructure of cast iron manufactured in 1940, 1952 and 1954 were gray cast iron. According to the classification of ASTM, all the pipes belong to the type A of graphite flake type chart, and the pipes manufactured in 1940 and 1952 belong to the size 4 of graphite flake size chart, and the pipes made in 1954 belongs to the size 5 .

(2) Comparing the fatigue strength of test pieces of the pipes of the same year with each other, the damaged pipes showed a very low strength in comparison to that of the series 2 taken out from unused pipes. The same tendency was shown about the static strength of test pieces.

(3) The test pieces, series 6 , were taken from the ductile pipe, and their static and fatigue strengths were higher than the others.

(4) In forming the test pieces, each of which has a rectangular section, the cast skin of the pipes was removed. These treatments must have produced conditions considerably different from the actual state of the pipes, so that the strengths obtained from the tests showed somewhat lower values.

(Received Nov. 5, 1957)

\section{1. 緒言}

上水道施設の普及, 执よび人口の増加にともない, 送，配水管のほとんどに大口径管が用らられるように なった。しかし，とて数年の間に各地に拁いて大口径 管の破裂事故が頻発し，乙かもとの破裂した大部分の 大口径管が, 現在諸都市で盛んに使用されている高級 鋳鉄管であるととは非常に大きな問題となっている。 一般飞破裂事故走起した高級鋳鉄管は, 施設後十数

* 原稿受付 昭和 32 年11月 5 日

** 正員 京都大学工学部

*** 阪神上水道市町村組合

昭和 33 年 3 月
年を経過しているが，まだ老朽化するとは相当寿命を 有しているものと思われる。

上水道送，配水用高級鋳鉄管の破裂原因として，管 材の強度, 流水の水理学的な問題, 埋設箇所の土質和 よど土圧, 交通荷重, 電食, 施工法などの各要素が考 えられる。しかし, 以上の各要素の中でも, 管枋の強 度は破裂に対し基本的なものであり，まず第 1 亿検討 する必要がある。

本研究は, 上水道送, 配水用高級鋳鉄管の破裂原因 究明の第 1 段階として, 破裂管, 扣よど製造年度, 管 
径, 管厚の異なる未使用管, 特飞昭和15年, 27 年, 29 年製飞重点を称き, 主として静的試験, 执よび痩労試 験走行破裂事故原因究明の一資料を得よらとしたも のである。

また，静的試験，㧅よび痩労試験飞付随して化学成 分分析試験，顕微鏡による金属組織の比較検討などを 行った。

\section{2. 試験 片}

試験片は10シリーズよりなり, 破裂管, 未使用管, 製造年度，管径，管厚の異なる10種類の高級鋳鉄管よ

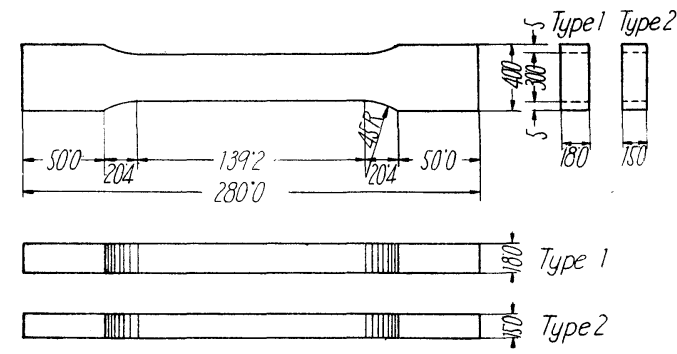

Fig. 1 Form and dimensions of fatigue test specimens
り採取し，各管とも6本の試験片を作製した。

試験片の採取は，管の長手方向にソケット側より 45 $\sim 85 \mathrm{~cm}$ の間で行った。乙の場合, 試験片は 1 力所に 执々て集中的に採取せす，管周 6 等分点のととろより 採取した。

試験片はFig. 1 亿示すような 2 種類の矩形断面を用 らた。これは管体より採取した弧状小割片の内側, 打 よび外側の鋳はだを削除して所定の形状に仕上げるた め, 試験片の厚さ最小削除量より決定したものであ って，管径が $1200 \mathrm{~mm}$ 以上のものにつ々ては $18 \mathrm{~mm}$, $600 \mathrm{~mm}$ のものにつネては $15 \mathrm{~mm}$ 厚とした。

試験片を採取した各管の製造年度, 管径, 管厚は Table 1 亿示したと抏りである. この中でシリーズ 1 以外はすべて未使用管である。

な祘, Table 1 Kは各管の化学成分分析試験結果克 併記した。

\section{3. 供試管材の化学成分および組織}

昭和 15 年, 27 年および 29 年製の高級鋳鉄管のソケ ット部乞管体部につレて化学成分ならびに顕微鏡組織 を調べを結果, Table 2 とPhoto. 1 を得を.

Table 1 Description of specimens for test series

\begin{tabular}{|c|c|c|c|c|c|c|c|c|c|c|c|}
\hline \multirow{2}{*}{$\begin{array}{c}\text { Series } \\
\text { No. }\end{array}$} & \multirow{2}{*}{$\begin{array}{c}\text { Manufac- } \\
\text { ured } \\
\text { year }\end{array}$} & \multirow{2}{*}{$\begin{array}{c}\text { Diameter } \\
\text { of pipe } \\
(\mathrm{mm})\end{array}$} & \multirow{2}{*}{$\begin{array}{c}\text { Thickness } \\
\text { of pipe } \\
(\mathrm{mm})\end{array}$} & \multirow{2}{*}{$\begin{array}{c}\text { Thickness } \\
\text { of } \\
\text { specimen } \\
(\mathrm{mm})\end{array}$} & \multicolumn{6}{|c|}{ Chemical composition } & \multirow{2}{*}{ Note } \\
\hline & & & & & T.C. & G.C. & $\mathrm{Si}$ & Mn & $\mathrm{P}$ & $\mathrm{S}$ & \\
\hline 1 & 1940 & 1200 & 32 & 18 & $3 \cdot 18$ & $2 \cdot 40$ & $1 \cdot 79$ & 0.85 & 0.229 & 0.068 & \multirow{5}{*}{$\begin{array}{l}\text { Fractured } \\
\text { by } \\
\text { accident }\end{array}$} \\
\hline 2 & 1940 & 1200 & 32 & 18 & $3 \cdot 50$ & $2 \cdot 88$ & $1 \cdot 58$ & $1 \cdot 18$ & 0.259 & 0.063 & \\
\hline 3 & 1952 & 1350 & 25 & 18 & $3 \cdot 27$ & $2 \cdot 63$ & $1 \cdot 03$ & 0.68 & $0 \cdot 164$ & 0.110 & \\
\hline 4 & 1954 & 1350 & 25 & 18 & $3 \cdot 47$ & $2 \cdot 75$ & $1 \cdot 34$ & $1 \cdot 15$ & 0.224 & $0 \cdot 166$ & \\
\hline 5 & 1954 & 1350 & 25 & 18 & $3 \cdot 34$ & $2 \cdot 32$ & $1 \cdot 31$ & 0.39 & 0.207 & 0.099 & \\
\hline 6 & 1955 & 1200 & 23 & 18 & $3 \cdot 51$ & - & $1 \cdot 64$ & 0.27 & 0.049 & 0.006 & \multirow{5}{*}{$\underset{\text { pipe }}{\text { Ductile }}$} \\
\hline 7 & 1952 & 600 & $15 \cdot 4$ & 15 & $3 \cdot 44$ & - & $1 \cdot 84$ & $0 \cdot 31$ & $0 \cdot 284$ & $0 \cdot 105$ & \\
\hline 8 & 1952 & 1200 & 23 & 18 & $3 \cdot 54$ & - & $1 \cdot 05$ & 0.97 & 0.213 & 0.078 & \\
\hline 9 & 1952 & 1200 & 23 & 18 & $3 \cdot 14$ & - & $1 \cdot 53$ & 0.67 & 0.201 & 0.097 & \\
\hline 10 & 1952 & 1200 & 23 & 18 & $3 \cdot 11$ & - & $1 \cdot 76$ & 0.62 & 0.175 & 0.095 & \\
\hline
\end{tabular}

Table 2 Chemical composition and hardness of the pipes manufactured in 1940, 1952 and 1954 .

\begin{tabular}{|c|c|c|c|c|c|c|c|c|}
\hline \multirow{2}{*}{$\begin{array}{l}\text { Manu- } \\
\text { factured } \\
\text { year }\end{array}$} & \multirow{2}{*}{$\begin{array}{c}\text { Sampling } \\
\text { part }\end{array}$} & \multicolumn{6}{|c|}{ Chemical compositon (\%) } & \multirow{2}{*}{$H_{B}$} \\
\hline & & T.C. & G.C. & $\mathrm{Si}$ & $\mathrm{Mn}$ & $\mathrm{P}$ & $\mathrm{S}$ & \\
\hline \multirow{2}{*}{1940} & Socket & $3 \cdot 27$ & $2 \cdot 06$ & $2 \cdot 05$ & 0.56 & $0 \cdot 162$ & 0.087 & - \\
\hline & Pipe body & $3 \cdot 21$ & - & $2 \cdot 15$ & $0 \cdot 70$ & $0 \cdot 182$ & $0 \cdot 105$ & 140 \\
\hline \multirow{2}{*}{1952} & Socket & $2 \cdot 99$ & $2 \cdot 02$ & $1 \cdot 52$ & 0.42 & 0.214 & $0 \cdot 108$ & - \\
\hline & Pipe body & $3 \cdot 02$ & $2 \cdot 11$ & $1 \cdot 47$ & 0.57 & 0.220 & 0.112 & 209 \\
\hline \multirow{2}{*}{1954} & Socket & $3 \cdot 16$ & $2 \cdot 21$ & $1 \cdot 48$ & 0.36 & 0.263 & $0 \cdot 112$ & - \\
\hline & Pipe body & $3 \cdot 11$ & - & $2 \cdot 01$ & 0.37 & 0.265 & 0.114 & 189 \\
\hline
\end{tabular}

Table 2 に示した化学成分分析値中 G.C. Kつい ては昭和15年，29年製の管の管体部の値が測定でき なかった。しかし，ソケット部の值から，昭和15年， 27 年製の両管はだ々たい同じような值を示している が, 昭和29年製の管は前二者よりやや大き々值を示 しているととがわかる.との 3 者間の品質の相異は Photo. 1 からも同じよらな傾向がらかがえる。す なわち, 昭和 15 年, 27 年, 29 年製の各管とも, 組織 は售通一般の鉜鉄に見られる灰鉄鋳鉄組織であって， 特に変ったところは見うけられないが，片状黒鉛の 形状々昭和29年製の管が他の管に比較し，その長さ が約 $1 / 2$ になっている。

ASTMの分類方法によると, Graphite flake type 


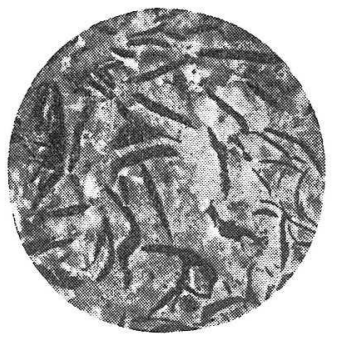

Manufactured in 1940 $(\times 100 \times 1 / 2)$

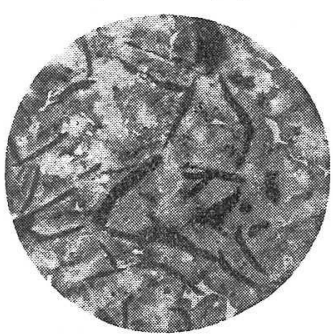

Manufactured in 1952 $(\times 100 \times 1 / 2)$

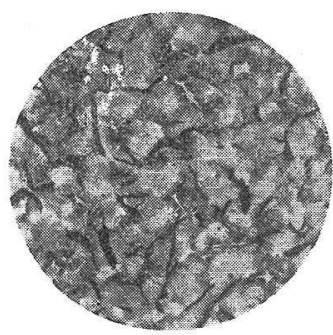

Madufactured in 1954 $(\times 100 \times 1 / 2)$

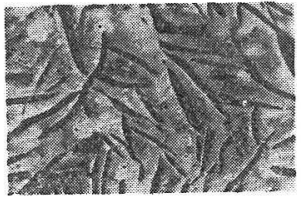

Manufactured in $1940(\times 100 \times 2 / 5)$

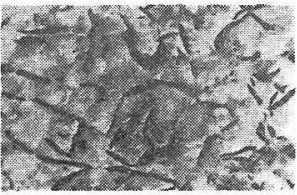

Manufactured in $1952(\times 100 \times 2 / 5)$

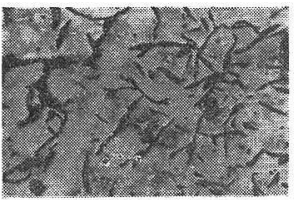

Manufactured in $1954(\times 100 \times 2 / 5)$

Pipe body part

衝揧などについて弱い欠 点があるものと思わ就 る。つきと昭和 29 年製は 細くわ儿曲して黑鉛が均 一火分布して扣り，他の All pearlite が完全な高 級鋳鉄の組織を示してい る。この種のものは強度 が高くじん性に富んでい

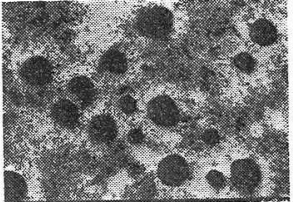

Manufactured in 1955 $(\times 100 \times 2 / 5)$

Photo. 2 Micrographs of ductile cast iron pipe

る.以上の実験から昭和 29 年製の管は他の 2 管に比べ 良品質であるととがわかった。店和，参考のたかシリ ーズ 6 の Ductile pipe の顕微鏡組織写真を Photo. 2 に示した。

Table 2 には管体部から採取しれ試鈳片の硬度走同 時に記しそ。

\section{4. 疲労試験およびその結果}

本実騃に使用しそ疲労試験機はローゼンハウゼン疲 労試験機 UHP 型（容量: 静荷重 20 ton, 動荷重 10 ton）で, 試験機の運転速度は $800 \mathrm{cycle} / \mathrm{min}$ を用い そ. 疲労試験注各シリーズとも $+1 \mathrm{~kg} / \mathrm{mm}^{2} \sim+\sigma_{\max }$

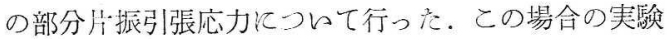
室温度は平均約 $12 \circ \mathrm{C}$ であった。

疲労試験により得られて結果は, 実験結果の判定考 明確にするそめ，縦軸を 3 倍に拡大した特殊両対数グ ラフを作製し, この縦妕上飞最大応力 $\sigma_{\max }$, 横軸上 に破断に至る回数 $N$ をとり，各シリ一ズの試験片に 対する実験結果㕝同一図上てプロットした。この結果 は Fig. 2 て示すとおりである。

Socket part

Photo. 1 Micrographs of high pressure cast iron pipes

chart からでは3者とも Type A である が, Graphite flake size chart からでは 昭和15年, 27 年製の両管は Size 4, 昭和 29 年製の管は Size 5 であるととがわかる。

つきに, 黒鉛の分布については, 昭和 15 年製のものは比較的良好な分布状態走示し ているが，その量が過大である点と，黒鏶 の周辺に Ferite が少し表わ好ている点が， この材質の強度の小なる原因であると考气 られる。これは戦時中の原料銑が不足した 時代に製造されたそめ, 組織が悪く製品が High silicon そなったととによるものであ る。しかしSteadite や硫化物の不純物は少 ないようである。昭和 27 年製の組織は All pearlite であるが，黒鉛の分布が不均一で あり形状も不揃らである。この中には多角 形の大きな Steadite が介在しているため,

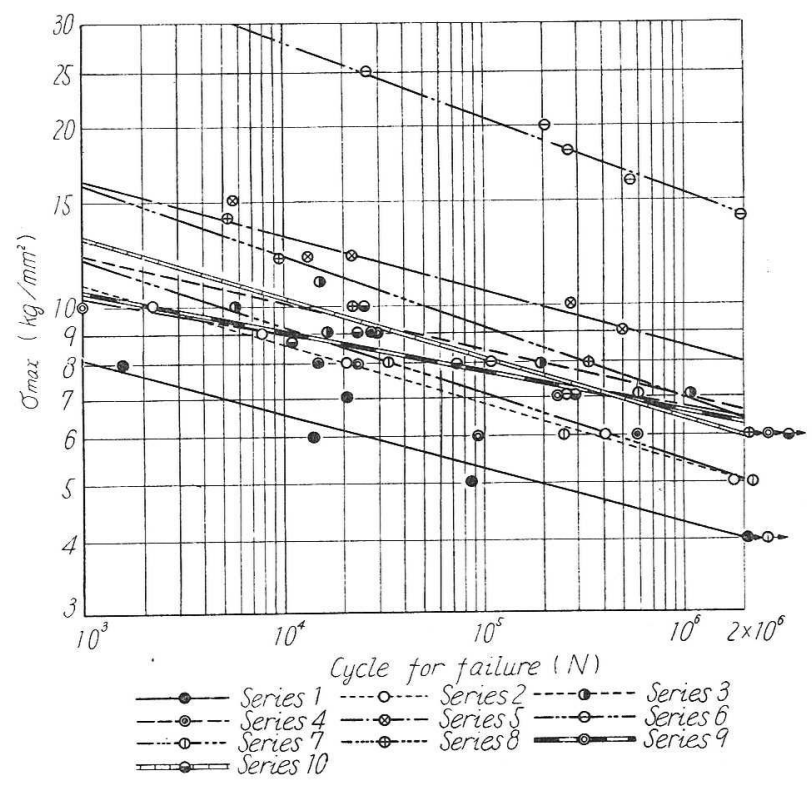

Fig. $2 S-N$ Diagram for all series 


\section{5. 実験結果の考察}

疲労試験の結果は, $S-N$ 線図として Fig. 2 亿示し そよらに，各シリーズに対しそれぞれの直線を得た。 この直線の傾斜 $K$ 孝用的 $n=2 \times 10^{6}$ の時間強度

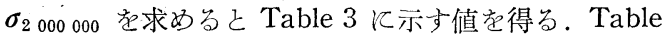
3 には, とのほかに痩労試験用試験片により静的引張 試験を行った結果も併せて記した。

Teble 3 Results of static tests and fatigue tests

\begin{tabular}{c|c|c|c}
\hline \begin{tabular}{c|c} 
Series \\
No.
\end{tabular} & $K$ & $\begin{array}{c}\text { Fatigue } \\
\text { strength } \\
\left(\mathrm{kg} / \mathrm{mm}^{2}\right)\end{array}$ & $\begin{array}{c}\text { Static strength } \\
\left(\mathrm{kg} / \mathrm{mm}^{2}\right)\end{array}$ \\
\hline 1 & 0.094 & 4.0 & 11.6 \\
2 & 0.103 & 5.0 & 15.8 \\
3 & 0.086 & 6.5 & 16.5 \\
4 & 0.062 & 6.4 & 14.2 \\
5 & 0.091 & 8.0 & 22.0 \\
6 & 0.135 & 14.0 & 44.9 \\
7 & 0.117 & 5.0 & 10.2 \\
8 & 0.121 & 6.4 & 19.1 \\
9 & 0.067 & 6.3 & 18.6 \\
10 & 0.104 & 6.0 & 17.0 \\
\hline
\end{tabular}

$\sigma_{200000}=\sigma \max (N / 2000000) K \quad K:$ Experimental constant

上水道送，配水管は一般に道路下に埋設されるもの であり，管は交通物の通過によりたえす繰返し荷重を らけるととになる。交通物としては主として自動車和 よび路面電車が考えられ, 配水管強度判定のための指 定繰返し数としては $n=2 \times 10^{6}$ が妥当な值であると考 えられる。

らま, 時間強度 $n=2 \times 10^{6}$ につ々て各シリーズの実 験結果を比較すると, Fig. 2 和よび Table 3 から, シリーズ 1 の疲労強度が特に低い值を示しているとと がわかる。乙れは昭和 15 年に製造され，送水中破裂 事故を起したものである。そとで同年に製造された未 使用管のシリーズ 2 の結果と比較すると, 静的強度拉 よび瘦労強度はともにいちじるしい低下をみせてい る.

他のシリーズは昭和 27 年から30年の間に製造された もので，未使用管ではあるが，だ々たいの傾向として 製造年代が新しいもの在ど, 静的強度秥よび痩学強度 は比較的良好な值走示している。

シリーズ 6 は Ductile cast iron pipe で, 静的強 度和よび病学強度は, 他のシリーズに比較して飛躍的 に高值走している。との管は戦後わが国に执いて 新しく用いられるよらになったもので，管体圧溒試験 に扣いても相当弾性を示し, 極限状態では高級鋳鉄管 のように破断するととなく鋼管のような性質を示して レる.
Fig. 2 和よど Table 3 の結果から昭和 29 年以降に 製造された管は比較的良好な結果を示しているが，乙 れは Photo. 1 からも明らかなよら飞, 片状黒鉛の形 状が昭和15年, 27 年に比較して微細で均等に分布して らるため，乙れが疲労強度に好影響を与えているもの と思われる。すな⿰ち, 昭和15年, 27 年製にみられる ように片状黒鉛が大をく粗雑に分布している場合, こ れがある程度切欠効果を与え疲労強度が低下するもの と考えられる.

試験片を作製する場合，弧状小割片から鋳はだを削 除して矩形断面に仕上げたのであるが，鋳鉄の鋳はで 部の強度は中央部のものより数\%高々值を有し, 試験 片の採取位置によって強度がかなり相異するととは周 知のと和りである。乙のため著者らが得た実験結果は 実際の值よりやや低々ものと思われる。

\section{6. 総括}

各種高級鋳鉄管より採取した試験片について静的試 験, 疲労試験执よびこれに付随して 2,3 の実験を行 ったが，得られた和もなる結果を総括すれば，つをの と和りである。

（1）昭和15年，27年和よび29年製に対する鋳鉄の 組織は灰銑鋳鉄組織であり, ASTM の分類方法によ ると Graphite flake type chart からでは 3 者とも Type A であるが, Graphite flake size chart から では昭和 15 年, 27 年製は Size 4 , 昭和 29 年製は Size 5 である。

(2) 疲労試験の結果, 各シリーズの $S-N$ 線注特 殊两対数目盛上に扣々て直線として得られた（Fig. 2 では縦軸は実験結果を明膫にするため横軸の3 倍にと った). 各シリーズの傾斜 $K$ は Table 3 に示す值を得 ॠ.

(3) $S-N$ 線図の傾斜 $K$ 在用的て $n=2 \times 10^{6}$ 亿対 する眭間強度を求め, Table 3 亿示す值を得を。

（4）破裂事故管より採取したシリーズ 1 試験片の 痩労強度は, Fig. 2 からわかるよらに, いちじるしい 低下をみせて和り，同年度に製造された未使用管から 採取したシリーズ 2 試験片と比較すると，前者は特に 低々值を示している。をた, 静的強度についても同様 の傾向を示している.

（5）シリーズ6は Ductile pipe より採取したも のであるが, 静的強度和よび疫労強度は他の管に比較 して飛躍的に高い值を示している。

今後, 重交通下に埋設される送, 配水管には, との ような管の使用されるととが望ましい。

（6）顕微鏡組織から，昭和15年，27年製のものは 同じよらな片状黒鉛組織を示して和り，昭和29年製の ものは前 2 者より微細な組織を示している. このとと は実験結果加疲労強度上に影響しているものと思わ 
れる。すなわち，片状黒鉊の形状が大であれば，乙れ がある程度切欠効果を高め, 疲労強度が低下するもの と考えられる。

（7）試験片を作製する場合，鋳はだを削除して矩 形断面に仕上げそが，このそめ著者らが得て実験結果 は実際の強度よりやや低ら値を示しているものと思わ れる。

以上, 各種高級鋳鉄管材の静的試験, 疲労試験和上 びこれと付随して 2，3 の実験を行って得を結果であ るが, 本研究化引委続き送, 配水管の破裂事故原因を
強度の面から多角的良查研究するため，著者らの一 部は $1500 \mathrm{~mm}$ 高級鋳鉄管の未使用の旧管叔よど新管 の圧壊試験，破裂管，未使用旧管，新管の時間強度線 ならびに（7)飞述べを事項については，高級鋳鉄管管 体より採取しそ試験片により曲ど試験を行い，その影 響を目下研究中である。

\section{参 考 文 献}

1) Amer. Found. Soc. Preprint, 20 (1954)

2）小西, 島田, 京都大学工研量報, 第10輯, 48 (1956)

\title{
漸増応力疲労試験結果への累積破損理論の適用*
}

\author{
榎本信助**

\begin{abstract}
An Application of the Idea of Cumulative Damage To the Results of Fatigue Tests Under Progressive Load
\end{abstract}

by

\author{
Nobusuke ЕNOMOTO \\ (Railway Technical Research Inst., Japanese National Railways)
}

\begin{abstract}
The Port method regarding the fatigue test of metals has pecently been appraised by many investigators. According to these results, $n$ in Eq. 1 in this paper takes different values for different materials and no systematic arrangement has been established yet for each kind of material. Even if the numerical values of $n$ are selected so that the experimental points may be located on a straight line, the extension of such line in most cases, deviates from a point equivallent to the Wöhler endurance limit on the abscissa. The author tried to obtain the equation of the $S-N$ curve and the $S-\alpha$ curve for progressive load fatigue making use of the general idea of cumulative damage, and got the results which would explain the above experimental data and clarify the relations between the $S-N$ curve and the $S-\alpha$ curve. From the above results, it might be said that caution must be exercised in determining the Wöhler fatigue limit by using the $S-\alpha$ diagram, because the curve plotted in this diagram does not form a straight line for what value of $n$, but is expected to form a complex curve as expressed by Eq. 4 in this paper.
\end{abstract}

\section{1. まえがき}

漸增応力度労試験酒よって, 而久限度を推定する方 法はProtによって提唱された。 この方法江直線的飞 増加する繰返し荷重による疲労破断のさらの応力と， 応力增加率の平方根とが直線関係を有すると仮定し,

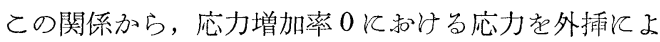
って求めると，乙れが $S-N$ 曲線泟和汀る疲労限と一 致するというのである. Portの理論によると，漸增灾 力による破断時の応力 $S_{R}$ 之, 応力增加率 $\alpha$ 之の間に

* 原稿受付 昭和32年11月22日，昭和30年11月26日関西支部秋季 講演会特よび昭和 32 年 10 月 29 日第 1 回材料試験連合講演会で講演 ** 正員 鉄道技術研究所
は，

$$
S_{R}=K \alpha^{n}, \quad n=0.5
$$

の関係がある。Kは定数である。

Prot 法についての評価は最近各所で行われている. これらを総括すると，(1)式江和けるnの值は材料に よってまちまちの值故とり，各材種によって整理でき

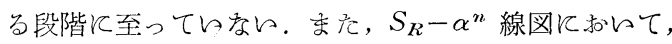
実験点が直線湴ぶように $n$ の值をとっても, その值 線の延長は $S$ 軸上の Wöhler 疲労限に相当する点か

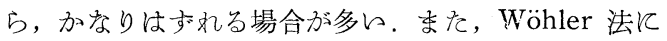

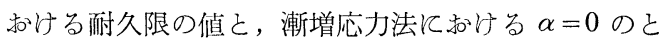
きの破断応力とが等価であると断定してよいが゙うか 